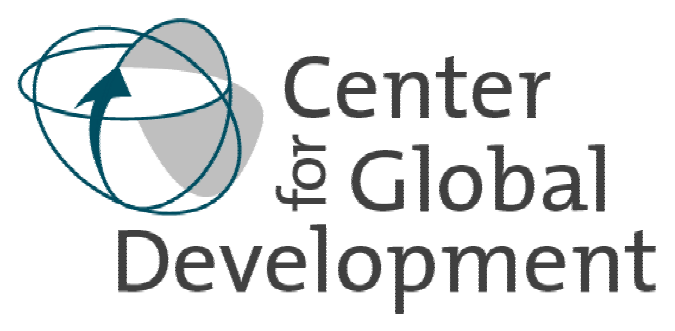

\title{
An Index of Industrial Country Trade Policy toward Developing Countries
}

By William R. Cline

\begin{abstract}
The index of trade policy developed in this study is designed to synthesize the state of developing country access to import markets in each of the major industrial country areas. The first section presents the theoretical considerations involved in constructing the index, and weighs the pros and cons of various approaches to measuring protection. The second section presents estimates of protection against imports from developing countries for Australia, Canada, the European Union, Japan, New Zealand, Norway, Switzerland, and the United States. These estimates are calculated for three broad product categories: textiles and apparel; other manufactures; and agricultural goods. The analysis then combines the sectoral estimates into an Aggregate Measure of Protection (AMP) for each importing country. It also reports measures of revealed openness, and incorporates them along with the AMPs to obtain a composite ranking of industrial countries by degree of market access. The study then considers the additional information gained by disaggregating protection among EU member countries (in light of variation in agricultural subsidies), reviews two other recent studies similarly ranking protection and compares them to the present study, and recapitulates the principal findings.

Among the big three markets, this study finds that protection against developing countries is lowest (and market access highest) in the United States, intermediate in the EU, and highest (market access lowest) in Japan. Among seven industrial countries plus the EU, market access is ranked highest for a cluster of three countries close to each other at relatively low protection levels (United States, Australia, New Zealand); followed by Canada and the EU, and then by Switzerland with somewhat lesser access. Significantly lesser market access is found in Japan and especially lowest-ranked Norway. For most countries, the results are driven heavily by estimates of agricultural protection, which is so high that it dominates the results even though the share of agriculture in total imports is modest. It is thus not surprising that the countries concentrated at the top of the market access league tend to be the agricultural exporting countries, and those at the bottom, agricultural importers.
\end{abstract}





\title{
An Index of Industrial Country Trade Policy toward Developing Countries
}

\author{
William R. Cline ${ }^{1}$ \\ Senior Fellow, Center for Global Development and Institute for International Economics*
}

\author{
Center for Global Development \\ Working Paper No. 14
}

October 2002

\footnotetext{
1 The author thanks Robert C. Johnson for excellent research assistance, including especially extensive research on data sources. For comments on an earlier draft he also thanks Philip Levy, Richard Newfarmer, and other participants in the Center for Global Development study group on ranking industrial country policies toward developing countries. "wcline@cgdev.org
} 


\section{Introduction}

The opportunity to expand exports is a key determinant of the prospects for economic growth in developing countries. Exports provide often-scarce foreign exchange, scope for economies of scale, and stimulus to productivity growth as developing countries seek to compete in international markets. The industrial countries have long recognized that trade matters, along with aid, in providing an environment in which developing countries can advance. They have even adopted special regimes (Generalized System of Preferences, GSP) granting special opportunities to developing countries.

The industrial countries have also maintained important trade barriers reflecting their domestic political constituencies, however. In manufactures, these have tended to fall most heavily on the goods naturally associated with developing countries' comparative advantage in unskilled-labor-intensive products (apparel, footwear, leather goods). In agriculture, the barriers designed to protect rural interests (often politically overrepresented) have tended to thwart the development of the other important area of natural comparative advantage of many developing countries: agricultural products relatively intensive in land and unskilled labor. Protection has affected both temperate (rice, grains, beef, dairy) and some tropical goods (sugar, orange juice). In both manufactures and agriculture, moreover, the legacy of past rounds of multilateral trade negotiations has tended to leave protection against goods important to developing countries higher than that against goods from industrial countries, in part because the developing countries in the past have tended to be free-riders under the principle of differential treatment and as a consequence have not been as active as industrial countries in putting their own protection on the negotiating table to secure reciprocal liberalization.

The index of trade policy developed in this study is designed to synthesize the state of developing country access to import markets in each of the major industrial country areas. The first section presents the theoretical considerations involved in constructing the index, and weighs the pros and cons of various approaches to measuring protection. The second section presents estimates of protection against imports from developing countries for Australia, Canada, the European Union, Japan, New Zealand, Norway, Switzerland, and the United States. These estimates are calculated for three broad product categories: textiles and apparel; other manufactures; and agricultural goods. The analysis then combines the sectoral estimates into an Aggregate Measure of Protection (AMP) for each importing country. It also reports measures of revealed openness, and incorporates them along with the AMPs to obtain a composite ranking of industrial countries by degree of market access. The study then considers the additional information gained by disaggregating protection among EU member countries (in light of variation in agricultural subsidies), reviews two other recent studies similarly ranking protection and compares them to the present study, and recapitulates the principal findings. 


\section{Measuring Barriers to Trade}

\section{Protection}

Conceptually the appropriate measure of protection is an aggregate weighted tariffequivalent of tariff and non-tariff barriers. Empirical measurement thus involves two challenges: obtaining tariff-equivalents for non-tariff restrictions, and applying the correct weights to individual tariffs and tariff-equivalents in arriving at the aggregate measure.

With respect to weighting, the classic choice is between weighting by import values and using simple unweighted averages. Both alternatives introduce potential biases. Importweighting suffers from the endogenous relationship of import values to protection levels, as high protection suppresses imports. There is a resulting downward bias in import-weighted protection. Unweighted averages suffer instead from randomness associated with the arbitrary value coverage of different individual tariff line categories. A third alternative is to weight by consumption or international production. However, this approach is usually impractical because available data typically refer to much broader sectoral consumption and production categories than the tariff line items, of which there are about 10,000 in the Harmonized Tariff System (HTS).

A practical and theoretically appealing alternative is to use "adjusted import weighting." This approach would apply weights reflecting some counterfactual magnitude of imports. Weighting by existing import values is analogous to a Laspeyres price index which uses initial period weights. One could weight by hypothetical import values under free trade, which would be analogous to a Paasche price index using terminal period weights. This study adopts the principle of weighting by the average of the actual and free-trade import value shares, which is analogous to the Fisher "ideal" price index. ${ }^{2}$ This in turn requires an implicit estimate of the free-trade magnitude of imports. As developed in Annex I, the estimates of this study choose for simplicity and transparency a uniform price elasticity of import demand of unity (and infinitely elastic export supply), which yields the following system of tariff weights: ${ }^{3}$

$$
\text { 1) } t^{*}=\sum_{i} \phi_{i} t_{i}
$$

where $t^{*}$ is the weighted average tariff, $t_{i}$ is the tariff rate in category $i$, and the weight $\varphi_{i}$ is calculated as:

\footnotetext{
${ }^{2}$ Although for simplicity the average here is arithmetic rather than geometric as in Fisher Ideal index.

${ }^{3}$ Annex II shows further that whereas weighting by some nonlinear function of the tariff could be appropriate if the focus of the analysis were welfare impact on the importing country, use of the tariff itself generates a close approximation when the focus is instead on the benefits for exporters, as in producers' surplus of the developing country exporters.
} 
2) $\phi_{i}=\frac{M_{i}\left(\frac{1+1.5 t_{i}}{1+t_{i}}\right)}{\sum_{i} M_{i}\left(\frac{1+1.5 t_{i}}{1+t_{i}}\right)}$

where $M_{i}$ is the value of imports in category $i$.

In further support of the use of adjusted import value weighting rather than simple unweighted averaging, Annex I shows that for a random sample of US tariffs, there is extreme variability in the value of imports covered (ranging from about $\$ 5$ billion in a single auto-part category to about $\$ 20,000$ in a minor chemical category). This means simple unweighted averages will be at the mercy of random chance and could generate a high average tariff derived from very high tariffs in a few trivial categories. At the same time, there is no apparent negative correlation between the magnitude of imports and the level of the tariff, suggesting that usual concerns about import endogeneity may be exaggerated. Indeed, it can be argued that in key high-tariff sectors such as textiles and apparel, high tariffs are a political response to high imports, so there is a possible positive rather than negative correlation between tariffs and import levels. If so, the risk of understating the tariff level may be greater using simple averages than using import-weighted averages.

The second principal empirical challenge, incorporating non-tariff protection, arises primarily in the key product sectors of agriculture and textiles and apparel, where such restrictions as quotas and tariff-rate quotas are especially important. The measure of protection developed below incorporates their protective effect into a total tariff-equivalent, $\tau$. The overall protection level of an industrial country against developing countries is thus calculated as:

\section{3) $P=\phi_{M} t{ }_{M}+\phi_{T} \tau *_{T}+\phi_{A} \tau{ }_{A}$}

where subscripts $M, T$, and $A$ refer to non-textile manufactures, textiles and apparel, and agriculture, respectively. The weights are again adjusted import weights (equation 2 ). ${ }^{4}$

Another potentially important complication is that preferential arrangements (including GSP; Lomé-Cotonou for the EU; CBI, ATPA, and AGOA for the United States) provide zeroduty or reduce-tariff treatment for many developing countries in many products. This may be thought of as causing different levels of protection against different developing countries even by a single industrial country (as emphasized by Bouet et al, 2001, who take this approach in calculating average protection for major industrial countries). However, because of country and product restrictions on preferences under the GSP and other similar regimes, and because much

\footnotetext{
${ }^{4}$ A reasonable question is whether double-counting of the import value adjustment occurs when the adjusted-import weight is used once at the within-sector level (e.g. for individual items in sector " $M$ ") and again when aggregating the three broad sectors. The answer is no. Experimentation with numerical values shows an infinitesimal upward bias from this source, whereas the alternative of using unadjusted import weights at the aggregate sector level gives a significant downward bias of aggregate protection in comparison with complete estimation at the detailed level.
} 
of trade enters duty free under MFN treatment, the revenue foregone has been extremely small. Thus, in 1997 the GSP tariff revenue foregone amounted to only \$1.6 billion for the European Union, \$240 million for the United States, and \$350 million for Japan (UNCTAD, 1999). This amounted to only 0.6 percent of total imports from GSP countries for the EU, 0.24 percent for the United States, and 0.2 percent for Japan. These magnitudes are sufficiently small that they can be ignored in arriving at aggregate protection levels against developing countries as a group.

The Aggregate Measure of Protection represented by equation 3) above is the preferred gauge of industrial country trade policy. This concept is essentially an aggregate tariffequivalent of tariff and non-tariff barriers. It is reasonable to ask, however, whether this measure is more appropriate than some nonlinear function of the aggregate tariff-equivalent, such as the square. Annex II demonstrates that whereas the square of the tariff is a more appropriate measure of the usual static welfare costs of protection form the standpoint of consumers in the importing country, for purposes of examining effects on developing country exports the level of the tariff-equivalent itself should provide a more meaningful measure.

Finally, it should be emphasized that the estimates below do not incorporate "contingent protection" such as anti-dumping penalties and countervailing duties against foreign export subsidies. Although these can be important, in the absence of any generally accepted method for their quantification there is no attempt to include them here. ${ }^{5}$

\section{Revealed openness}

Because of difficulties in estimating protection, especially for the tariff-equivalent of non-tariff barriers, and because it is widely believed that in at least one key industrial country (Japan) there are various "tacit" barriers that have the effect of restraining imports even where formal protection is absent, it is also important to consider the "revealed" openness of markets. This is best done by examining the level of actual imports from developing countries against some economic benchmark. The usual benchmark is GDP.

A well-known international pattern is that smaller economies tend to have a higher ratio of imports to GDP. For the eight economies examined here, this pattern is confirmed for total imports. ${ }^{6}$ One approach, then, would be to normalize the openness test for size of the economy.

It turns out, however, that there is no clear relationship of the import/GDP ratio to size of the economy for imports from developing countries. ${ }^{7}$ This may reflect the fact that whereas countries such as Sweden and Switzerland import heavily from the EU to obtain the full complement of differentiated manufactured products ("intra-industry trade"), as a consequence

\footnotetext{
5 Simple "counts" of anti-dumping and countervailing initiatives are sometimes cited; "coverage" ratios can also be calculated (the fraction of imports in categories in which these restraints are present). Neither approach takes account of the intensity of the restraint, however, or of the degree to which the restraint exceeds that which might appropriately be warranted by true dumping and subsidization.

${ }^{6}$ A regression of total imports (CIF) as a percentage of GDP on the logarithm of GDP (billions of dollars) for 2000 yields: $\mathrm{z} 1=46.4$ (5.7) $-3.734 \ln \operatorname{GDP}(-3.0)$; adj. $\mathrm{R}^{2}=0.48$; t-statistics in parentheses.

${ }^{7}$ For these imports, the corresponding regression is: $\mathrm{z} 2=5.15(2.9)+0.086 \ln \mathrm{GDP}(0.32)$; adj. $\mathrm{R}^{2}=0.013$.
} 
of small domestic markets, the same economies do not differ as much from the large industrial economies (US, EU) with respect to needs for imports of labor-intensive and resource-based goods ("interindustry" or "Heckscher-Ohlin" trade). In any event, the absence of an international trendline relating import/GDP ratios to GDP size for imports from developing countries means there is no basis for normalizing the raw import ratios in gauging openness to imports from these countries. ${ }^{8}$

Imports of manufactures from developing countries, relative to GDP, provide a second measure of revealed openness. The rationale for a separate focus on manufactured goods is that all industrial countries have manufacturing sectors from which protectionist pressures can arise, whereas several do not have significant domestic supplies of oil and some other natural resources, and relatively high imports of these raw materials can overstate the openness of trade policy. A third measure of revealed openness is the ratio of imports from "at risk" developing countries - Highly Indebted Poor Countries (HIPC), Least Developed Countries (LDCs), and Sub-Saharan Africa - to GDP. The rationale for this separate measure is some broad notion of greater urgency of ensuring export opportunities for these countries.

\section{Estimation}

Tariffs on manufactured goods -- Finger and Schuknecht (1999) report that the post-Uruguay Round average MFN tariff of industrial countries on imports of manufactures from developing countries stands at 3 percent. This is about twice as high as the average for imports from industrial countries. A first step in arriving at an index for industrial country protection is to obtain this average separately for each developed country market.

The WTO (2002, p. 17) has compiled estimates of post-Uruguay Round tariffs. ${ }^{9}$ For imports from all sources, the simple (unweighted) average ("bound") tariff on industrial goods (excluding petroleum) stands at 3.9 percent for the United States, 4.1 percent for the European Union, 3.5 percent for Japan, 5.2 percent for Canada, 3.4 percent for Norway, 1.8 percent for Switzerland, 14.2 percent for Australia, and 12.7 percent for New Zealand.

These tariff estimates are simple, unweighted averages. It would be preferable to obtain the corresponding "adjusted import weighted" averages applying equations 1) and 2) above, but this remains a task for future research. Similarly, in the absence of special compilation, there are no corresponding averages yet available for imports from developing countries. It is to be expected, however, that these averages would be higher. As an approximation, it is possible to use average tariffs by major trading partner country reported by Gelhar et al $(1997$, p. 91$)$ to obtain an idea of the ratio of the average tariff on goods from developing countries to that on

\footnotetext{
${ }^{8}$ Although it would be possible to construct a model of international trade patterns for use as the benchmark in normalizing in the openness tests, such an approach would run counter to the intent of keeping the index as simple and transparent as possible, and would also raise questions about the particular model chosen.

${ }^{9}$ Phase-in for the new tariffs was to be completed over 5 years beginning in 1995 for industrial goods, and over 6 years for agricultural goods (WTO, 2002, p. 1).
} 
goods from industrial countries. ${ }^{10}$ It should be noted that these tariffs are those prevailing prior to conclusion of the Uruguay Round, and the assumption must be made that the relationship of tariffs facing developing countries to those facing industrial countries remained the same after the Uruguay Round cuts even though levels of both declined. On the basis of these ratios, the shares of developing and industrial countries in total imports, ${ }^{11}$ and the WTO tariff averages, we obtain an average manufacturing tariff for goods from developing countries of 4.6 percent for the United States, 5.0 percent for the European Union, and 3.6 percent for Japan, 6.4 percent for Canada, 12.8 percent for Australia, and 11.6 for New Zealand. ${ }^{12}$ Gelhar (1997) does not report comparable tariff averages for Switzerland or Norway. Therefore, the estimates here apply the average ratio of tariffs applicable to developing countries relative to developed country suppliers for the US, EU, Japan, and Canada and estimate average manufacturing tariffs of 2.37 percent for Switzerland and 4.47 percent for Norway.

Figure 1

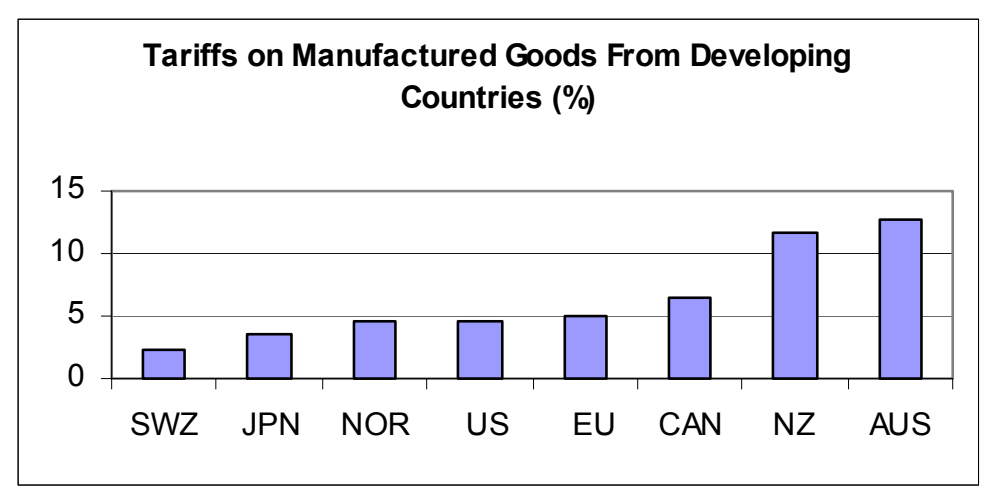

Source: WTO (2002), Gehlar et al (1997)

\footnotetext{
${ }^{10}$ The tariff averages are for all merchandise, not just manufactures. The unweighted average tariff facing 18 developing country partners (Korea, Indonesia, Malaysia, Philippines, Singapore, Thailand, China, Hong Kong, Taiwan, Argentina, Brazil, Mexico, other Latin America, sub-Saharan Africa, Middle East-North Africa, Eastern Europe, Southern Asia, and Rest of World) stands at 5.68 percent for the United States, 6.98 percent for the EU, 4.36 percent for Japan, 8.22 for Canada, 12.78 for Australia, and 19.43 for New Zealand. The corresponding unweighted average tariff on imports from industrial country partners (Australia, New Zealand, United States, Canada, Japan, and EU) is 3.9 percent for the United States, 4.88 percent for the EU, 4.02 percent for Japan, 6.36 percent for Canada, 15.0 percent for Australia, and 22.1 percent for New Zealand. The ratio of developing to developed country suppliers for these tariffs, which are circa mid-1990s rather than post-Uruguay Round, is thus 1.46 for the United States, 1.43 for the EU, 1.08 for Japan, and 1.29 for Canada, but only 0.85 for Australia and 0.88 for New Zealand.

${ }^{11}$ The share of developing countries in total imports in 2000 was 0.493 for the United States, 0.415 for the European Union (excluding intra-EU trade), 0.605 for Japan, .163 for Canada, .288 for New Zealand, .378 for Australia, .14 for Switzerland, and .184 for Norway (calculated from IMF, 2002b).

${ }^{12}$ That is: $t_{I C}=t /\left(\varphi_{D C} \lambda+\varphi_{I C}\right)$ and $t_{D C}=\lambda t_{I C}$, where $t$ is the average (WTO) tariff, subscripts IC and DC refer to industrial country and developing country suppliers respectively, and $\lambda$ is the estimated ratio $t_{\mathrm{DC}} / \mathrm{t}_{\mathrm{IC}}$.
} 
Tariff-equivalents for textiles and apparel - The computation of average protection levels in the textiles and apparel sector is complicated by the fact that imports face both tariff and quantitative barriers under the Multi-Fiber Arrangement (MFA). Francois and Spinanger (2002) have estimated the export tax equivalents (ETEs) ${ }^{13}$ of protection on textiles and apparel for the United States and European Union against imports from a number of major developing countries and developing country areas. ${ }^{14}$ Although the Uruguay Round's Agreement on Textiles and Clothing (ATC) provides for the phase out of MFA quotas, the broad levels of protection should still be relevant both because the ATC permits the bulk of liberalization to be delayed until 2005 and because it seems likely that developed countries will maintain safeguard and other contingent protection for textiles and apparel beyond the transition period.

For the United States, weighting by imports from developing countries (USITC, 2002, SITC categories 65 and 84), the average export tax equivalent of quotas is 9.1 percent for textiles and 11.4 percent for apparel. For the EU, the corresponding weighted averages (using import data from WTO, 2001, pp. 146, 153) are 5.1 and 5.2 percent, respectively. For Japan, which historically has not applied MFA quotas (Cline, 1990, p. 137), tariff equivalents of quotas are set at zero. The GTAP5 database assumes that Canada's tariff-equivalents of quotas are the same as those for the United States. In the absence of specific estimates for the other four industrial countries examined in this study, the estimates below apply an average of the estimates for the United States and the EU.

In addition to quota protection, the major industrial countries also typically impose relatively high tariffs on textiles and apparel. Dimaranan and McDougall (2002) report importweighted tariffs for the two sectors. Table 1 reports these estimates, along with the quota tariffequivalents (ETEs) and the relative weights of textiles and apparel in imports from developing countries. ${ }^{15}$ This information is combined to arrive at an overall tariff-equivalent for textiles and apparel for each industrial country (table 1 and figure 2).

The results confirm that protection is much higher in textiles and apparel than for other manufactured goods. Thus, whereas tariffs on imports from developing countries are typically 5 percent or below for manufactures overall (figure 1), for textiles and apparel they are typically in the range of 20-30 percent (figure 2).

\footnotetext{
${ }^{13}$ The export tax equivalents (ETEs) provide a measure of the restrictiveness of a quantitative restraint. They can be thought of as equal to the tariff barrier that would generate the same gap between domestic and world prices as that which is generated by the quantitative restraint.

${ }^{14}$ South Asia, Latin America, Eastern Europe, China, Hong Kong, Korea, Indonesia, Malaysia, Philippines, Singapore, Taiwan, Thailand, India, Vietnam, Sri Lanka, Mexico, and Turkey.

${ }^{15}$ Trade data are from OECD (2002a), for Harmonized Tariff System chapters 50-60 (textiles) and 61-64 (apparel).
} 
Table 1

Tariffs and tariff-equivalents of quotas in textiles and apparel (\%)

US Canada EU Australia N. Zealand Switzerland Japan Norway

\begin{tabular}{|c|c|c|c|c|c|c|c|c|}
\hline $\begin{array}{l}\text { Tariffs: } \\
\text { textiles }\end{array}$ & 11.2 & 15.7 & 9.7 & 17.0 & 8.6 & 0.7 & 8.5 & 13.8 \\
\hline apparel & 13.3 & 21.2 & 12.1 & 29.3 & 25.0 & 17.5 & 12.5 & 17.5 \\
\hline $\begin{array}{l}\text { Quota tariff-equivalents } \\
\text { textiles }\end{array}$ & 9.1 & 9.1 & 5.1 & 7.1 & 7.1 & 7.1 & 0.0 & 7.1 \\
\hline apparel & 11.4 & 11.4 & 5.2 & 8.3 & 8.3 & 8.3 & 0.0 & 8.3 \\
\hline $\begin{array}{l}\text { Combined protection: } \\
\text { textiles }\end{array}$ & 21.3 & 26.2 & 15.2 & 25.3 & 16.3 & 7.8 & 8.5 & 21.9 \\
\hline apparel & 26.2 & 35.0 & 17.9 & 40.0 & 35.4 & 27.2 & 12.5 & 27.2 \\
\hline Import weights: & & & & & & & & \\
\hline $\begin{array}{l}\text { texiles } \\
\text { apparel }\end{array}$ & $\begin{array}{l}0.155 \\
0.845\end{array}$ & $\begin{array}{l}0.303 \\
0.697\end{array}$ & $\begin{array}{l}0.282 \\
0.718\end{array}$ & $\begin{array}{l}0.315 \\
0.685\end{array}$ & $\begin{array}{l}0.266 \\
0.734\end{array}$ & $\begin{array}{l}0.155 \\
0.845\end{array}$ & $\begin{array}{l}0.229 \\
0.771\end{array}$ & $\begin{array}{l}0.096 \\
0.904\end{array}$ \\
\hline $\begin{array}{r}\text { Combined protection: } \\
\text { textiles and apparel }\end{array}$ & 25.4 & 32.3 & 17.2 & 35.4 & 30.3 & 24.2 & 11.6 & 26.7 \\
\hline
\end{tabular}

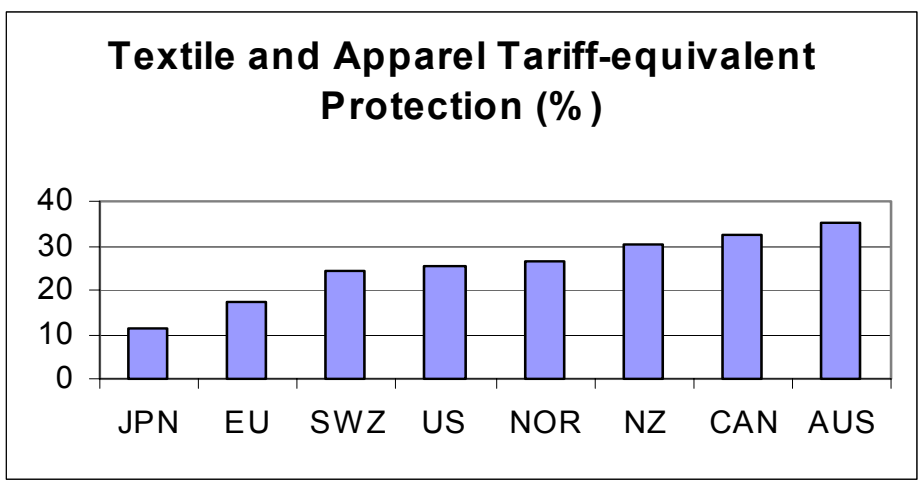

Figure 2

Source: see text.

Agricultural protection - The same international database provides estimates of post-Uruguay Round bound-tariff protection against agricultural goods. Dimaranan and McDougall (2002) provide tariff protection estimates (including the ad-valorem equivalents of specific tariffs) for rice, wheat, other grains, meat, and milk (as well as other categories). Where there are tariff-rate quotas, as a consequence of the Uruguay Round's conversion of quotas into tariff-rate quotas, the rates reported are the average between the in- and over-quota tariff rates (Gibson, Wainio, and Whitley, 2002). The resulting estimated tariffs range as high as 409 percent for protection of rice in Japan. When the protection rates are weighted by estimates of world output value for the corresponding products (MacLaren, 1997, p. 214), the resulting weighted average tariff rates are 
2.5 percent for Australia, 5 percent for New Zealand, 11 percent for the United States, 63 percent for Canada, 67 percent for the EU, 161 percent for Switzerland, 202 percent for Japan, and 273 percent for Norway (Figure 3).

Figure 3

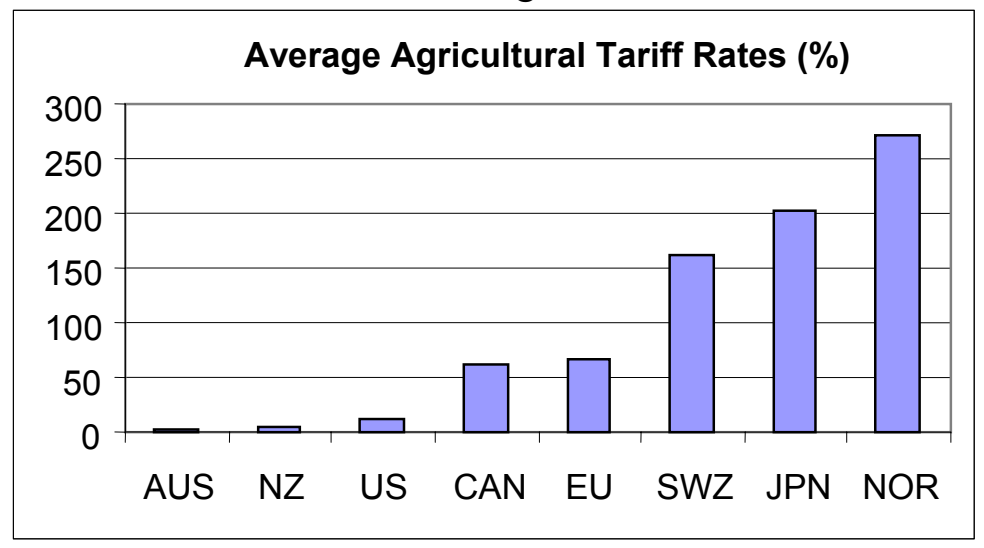

In addition to tariffs, farm subsidies contribute substantially to agricultural protection. In the Uruguay Round the amounts of these that were considered to have trade distortive effects were summarized as the "Aggregate Measure of Support" (AMS). Under the Uruguay Round Agreement on Agriculture, AMS levels were bound, and countries committed to reducing these levels over time. As of 1998 (or closest year with AMS reported), the actual levels of the AMS were: $\$ 6.2$ billion for the United States, $€ 51$ billion for the EU, ¥3.17 trillion for Japan, \$A 132 million for Australia, \$C 619 million for Canada, Kr 10.9 billion for Norway, and SF3.3 billion for Switzerland (WTO 2002, p. 58). For the United States, a more meaningful AMS is the bound level (\$20.7 billion). The reason is that new legislation in 2002 effectively set US agricultural subsidies at this level over the next decade. At 1998 exchange rates, and in light of the share of agriculture in GDP (3 percent for Australia and New Zealand, 2.3 percent for the EU, and 2 percent for the United States, Japan, and the other countries considered; World Bank, 2001, pp. 296-97), the AMS subsidies (bound for the US, actual for the others) amount to 9.8 percent of agricultural production for the United States, 26.4 percent for the EU, and 30.7 percent for Japan, 43.0 percent for Switzerland, and 49.1 percent for Norway, but only 2.3 percent for Canada, 0.8 percent for Australia, and zero for New Zealand (figure 4). 


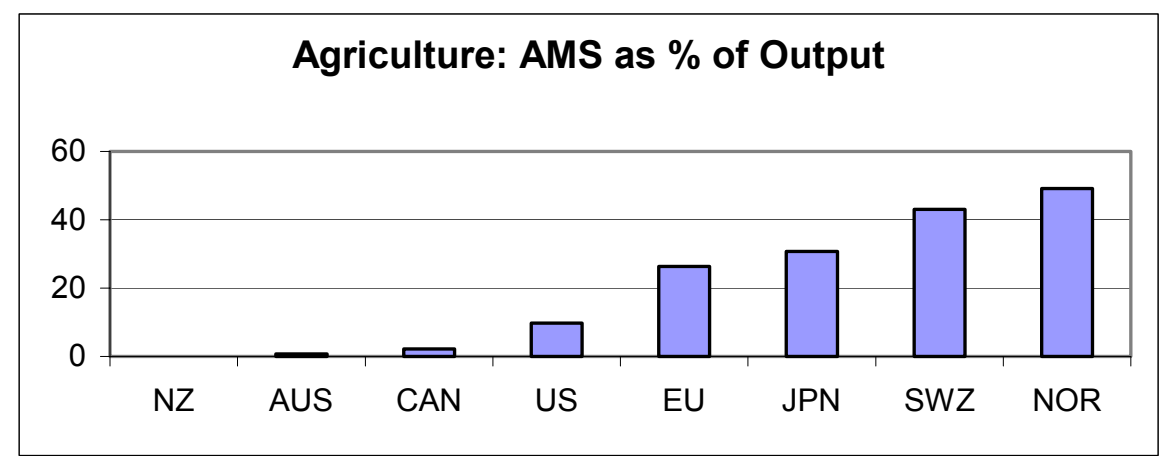

Figure 4

In order to arrive at total agricultural protection, it is necessary to obtain the combined effect of tariffs and subsidies. Annex III sets forth a methodology for obtaining the tariff-equivalent of the agricultural subsidy as a function of the subsidy rate and the ratio of domestic output to imports. Using this method, and assuming that the elasticity of domestic supply is unity, the AMS subsidies translate into tariff-equivalent levels of zero for New Zealand, 1.8 percent for Canada, 2.6 percent for Australia, 8.6 percent for Norway, 9.8 percent for Japan, 10.0 percent for Switzerland, 19.6 percent for the EU, and 20.8 percent for the United States (figure 5).

An important finding in these estimates is that because the US domestic production base is large relative to imports, a modest amount of production subsidy balloons into a relatively larger tariff-equivalent as the resulting magnitude of imports displaced is large relative to the small import base. Conversely, for Switzerland, Norway, and Japan, the relatively small base of domestic agriculture when valued at world prices, and higher relative weight of imports, means that high domestic subsidy rates (30-50 percent) translate into only moderate tariff-equivalents (all about 10 percent). ${ }^{16}$ These results are somewhat counterintuitive, as they conclude that in terms of the protective effect against imports, US agricultural subsidies are the highest among the eight industrial economies considered, a finding that would not be obvious from the wellknown US comparative advantage in agriculture.

Figure 5

\footnotetext{
${ }^{16}$ The intuition is as follows. Suppose the country imports almost all of its agricultural consumption, but has a tiny domestic sector that is heavily subsidized. The increment in domestic output resulting from the subsidy is small relative to imports even if large relative to what would otherwise be produced domestically, so the subsidy is equivalent to only a small tariff burden to imports.
} 
Table 2

Aggregate Protection Measure

US

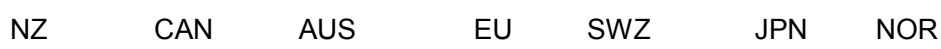

Tariff equivalent in: (\%)

Manufactures

Textiles and apparel

Agriculture

Fuels

Sectoral shares, imports

from developing countries (\%)

Manufac. exc. Tx \& Ap.

Textiles and apparel

Agriculture

Fuels

$\begin{array}{rr}4.6 & 12.3 \\ 25.4 & 30.3 \\ 34.4 & 5.0 \\ 0 & 0\end{array}$

5.4
32.3
65.5
0

13.4

35.4

35.4
5.2

5.0

17.2

100.2

1.9

24.2

187.1

3.6
11.6

11.6

231.9

3.6

26.7

12.5

5.6

63.7

74.9

11.9

9.2

0

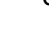

0

12.6

14.3

69.7

9.7

72.2

41.8

9.8

57.3

$\begin{array}{ll}7.9 & 5.6\end{array}$

$11.7 \quad 10.5$

$11.1 \quad 11.4$

13.5

15.2

14.9

19.5

$5.9 \quad 34.3$

2.3

Adjusted sectoral weights:

Manufac. exc Tx \& Ap

Textiles and apparel

Agriculture

$68.4 \quad 63.9$

63.9

73.4

70.0

55.7

69.1

10.9

14.4

40.4

9.8

6.1

9.8

9.1

5.5

13.4

17.3

15.0

Fuels

12.2

13.6

14.1

18.4

32.6

2.1

Weighted average

protection

import weights

$8.6 \quad 12.2$

12.2

$\begin{array}{ll}13.1 & 13.3 \\ 13.7 & 14.1\end{array}$

18.3

30.9

42.7

100.0

adjusted weights

$8.9 \quad 12.8$

Figure 6

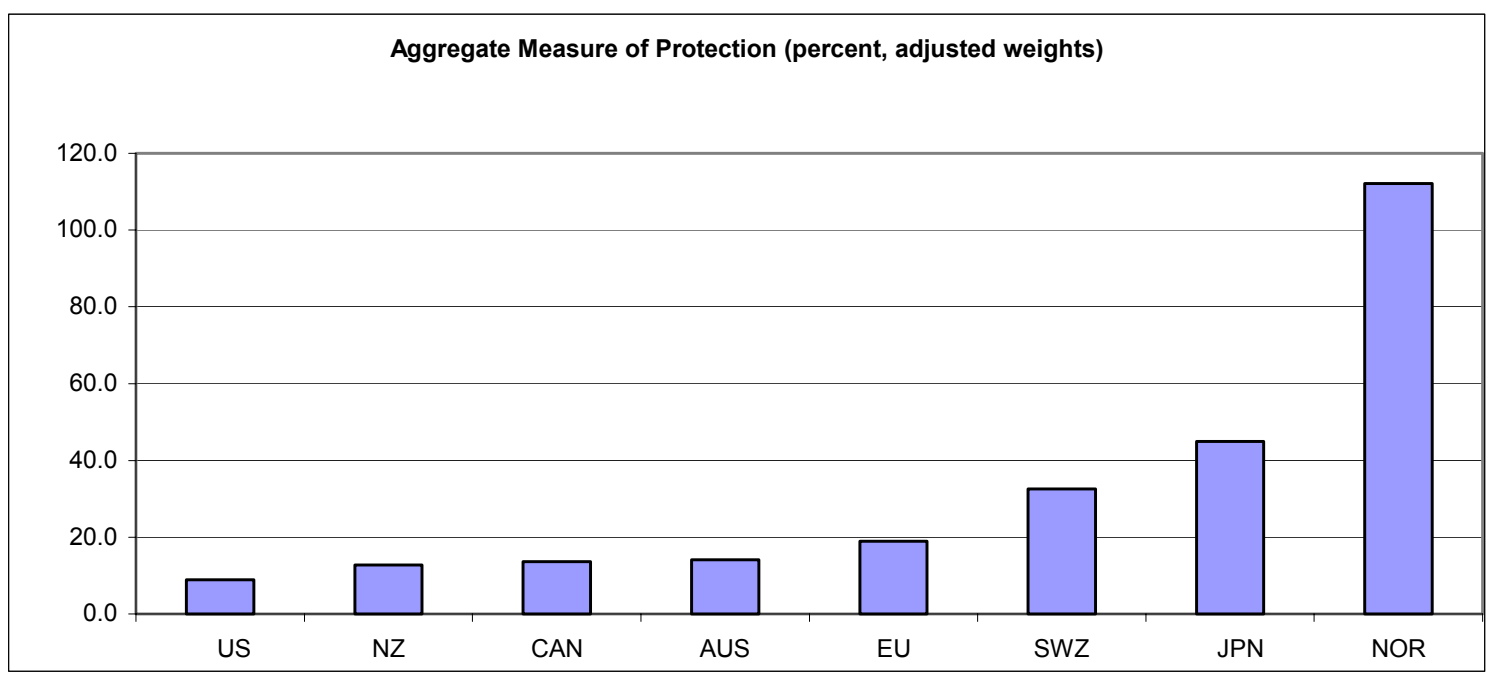

Import ratios -- The International Monetary Fund (IMF, 2002b) provides data on total imports by trading partner. For 2000, these show that the United States imported $\$ 610.6$ billion from developing countries, the EU, \$549.9 billion, and Japan, \$229.6 billion. These amounts corresponded respectively to 6.19 percent, 7.0 percent, and 4.83 percent of GDP. The comparable rate for Norway is 3.6 percent; for Switzerland, 4.8 percent; for Canada, 6 percent; for Australia, 7.4 percent; and for New Zealand, 8 percent. (See Figure 7). 
Data on manufactured imports are less precise. For the EU and Japan, they may be approximated from compilations by the WTO (2002). ${ }^{17}$ These data show that in 2000, the EU imported $\$ 330.9$ billion from the developing countries, and Japan, $\$ 113.7$ billion. More detailed data on manufactured imports for the United States place their total from developing countries at $\$ 447.1$ billion. The corresponding shares in GDP are: for the United States, 4.5 percent; EU, 4.21 percent; and Japan, 2.39 percent. Comparable rates were compiled for Australia, Canada, Norway, and New Zealand for 1999 and for Switzerland in 1998 from OECD (2002d). (See Figure 7).

Figure 7

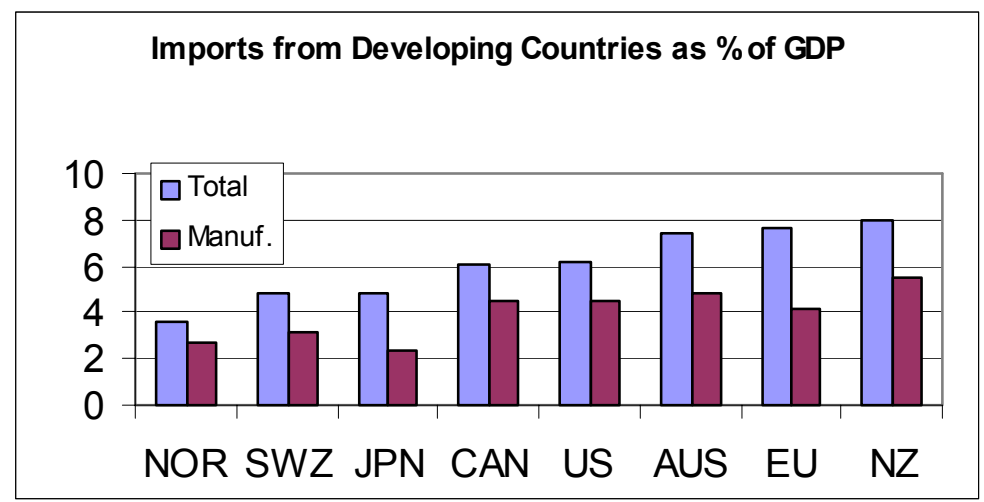

Whether measured by total imports or by imports of manufactured goods, these import ratios show Japan as less open than the United States and Europe, and by a significant margin. In contrast, the United States and Europe are much closer together in their revealed openness, especially considering that on total imports the EU is slightly more open whereas on manufactured imports the United States is.

The data aggregations also provide an opportunity to place trade with developing countries in perspective. It turns out that for both Europe and Japan, imports from developing countries are higher than those from industrial countries (excluding intra-EU trade), and for the United States, imports are divided almost evenly between developing and industrial country suppliers. In contrast, for all the smaller industrial countries, imports from developing countries comprise a smaller share of the total (ranging from 12 percent for Switzerland to 28 percent for Australia). For the big three economies, the fact that developing countries account for more than

\footnotetext{
${ }^{17}$ The WTO data aggregate "Asia" as a region. Supply from Japan, Australia and New Zealand must be subtracted to obtain developing Asia. It is assumed that all exports from Japan are manufactured goods. For Australia and New Zealand, exports to the EU in manufactures are estimated by applying to total exports (IMF, 2002b) the shares of manufactured goods WTO (2002, p. 116): 0.238 for Australia, 0.3 for New Zealand. For the United States, manufactured imports are estimated as Standard International Trade Classification (SITC) categories 5 through 9 (USITC, 2002). Developing country supply is obtained as total less OECD plus Mexico, Korea, Hungary, and Turkey.
} 
half of imports means that even if protection were at identical levels, more than half of the remaining impact of potential trade liberalization would be in increased trade flows from developing countries; and because protection levels against developing countries are in fact higher than against industrial countries, the implication is even stronger that the greater part of unfinished business in trade liberalization resides in access of developing countries to the big three industrial country markets (and likely, though not analyzed here, conversely). ${ }^{18}$

Figure 8

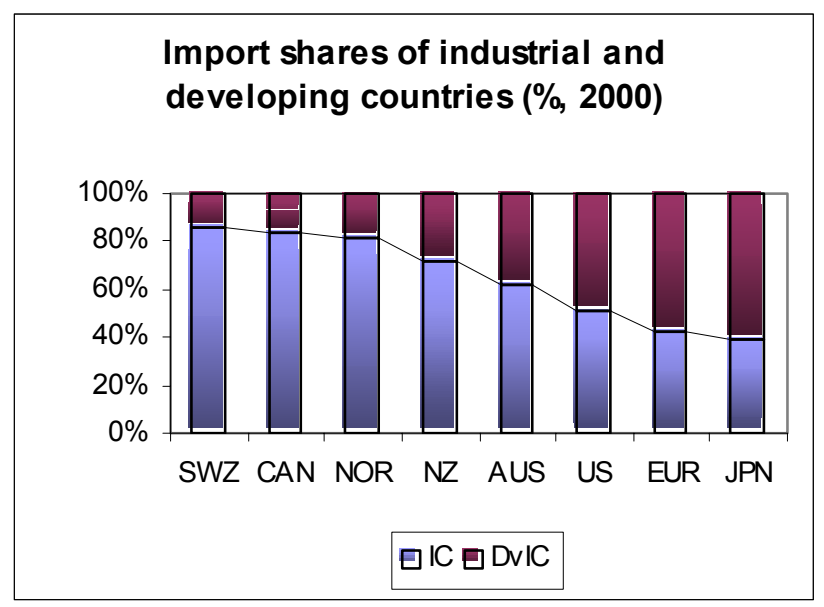

Imports from at-risk developing countries - The third variation of the import ratio is that using imports from countries that are poor and "at risk" in the sense that they have been identified as a member of at least one of three international regimes oriented toward poor countries with fragile economies: the Highly Indebted Poor Countries (HIPCs), Least Developed Countries (LDCs), or sub-Saharan African countries (SSA). There are a total of 64 countries with an aggregate population of 1.0 billion that are members of at least one of these three groupings. In 2000, total imports from these countries amounted to 0.16 percent of GDP for Japan, 0.20 percent for Norway, 0.21 percent of GDP for Norway, 0.24 percent for New Zealand, 0.34 percent for the United States, 0.56 percent for the EU, and 0.57 percent for Australia (figure 9). ${ }^{19}$

\footnotetext{
${ }^{18}$ Note that the high share of developing countries the big-three import markets also challenges the popular perception that North-North trade dominates world trade flows. This perception probably arises because trade aggregates frequently count intra-EU trade. Viewing the EU as a single country for trade purposes sharply reduces the share of industrial countries in global exports. Note further that, correspondingly, much of trade theory geared toward explaining the "paradox" of North-North trade, which does not fit traditional (Heckscher-Ohlin) relative factor endowment explanation of comparative advantage (because industrial countries have similar rather than complementary factor endowments), is of less relevance than might be thought.

${ }^{19}$ Calculated from IMF (2002a, 2002b).
} 


\begin{tabular}{|l|c|c|c|c|}
\hline & $\begin{array}{l}\text { Aggregate } \\
\text { Measure of } \\
\text { Protection: } \\
\text { Level (\%) }\end{array}$ & Rank & Rank & Revealed Openness \\
\hline United States & 8.9 & 1 & 4 & $\begin{array}{c}\text { Composite } \\
\text { Rank }\end{array}$ \\
\hline New Zealand & 12.8 & 2 & 2 & 2 \\
\hline Australia & 14.1 & 4 & 1 & 3 \\
\hline Canada & 13.7 & 3 & 5 & 4 \\
\hline European Union & 18.9 & 5 & 3 & 6 \\
\hline Switzerland & 32.5 & 6 & 6 & 7 \\
\hline Japan & 45.0 & 7 & 8 & 8 \\
\hline Norway & 112.1 & 8 & 7 & \\
\hline
\end{tabular}

Another approach to obtaining a composite ranking is to use the " $Z$ statistic" to take into account not only the ordinal ranking on the individual components but also the intensity of the differences between the countries on each scale. The $\mathrm{Z}$ statistic is the ratio of the difference from the mean to the standard deviation. Using the negative of the AMP (so that the lowest protection has the highest $\mathrm{Z}$ score), and obtaining the average of the three revealed-openness $\mathrm{Z}$ statistics, one obtains the rankings shown in table 4.

Table 4

Composite Ranks by Z Statistics 


\begin{tabular}{|l|l|l|l|l|l|l|}
\hline & $\begin{array}{l}\text { Aggregate } \\
\text { Measure } \\
\text { of } \\
\text { Protection }\end{array}$ & Rank & $\begin{array}{l}\text { Zpenness } \\
\text { Z }\end{array}$ & Rank & $\begin{array}{l}\text { Composite } \\
\text { Z }\end{array}$ & $\begin{array}{l}\text { Composite } \\
\text { Z Rank }\end{array}$ \\
\hline US & 0.678 & 1 & 0.196 & 4 & 0.558 & 3 \\
\hline New Zealand & 0.564 & 2 & 0.674 & 3 & 0.592 & 2 \\
\hline Canada & 0.538 & 3 & -0.096 & 5 & 0.380 & 5 \\
\hline Australia & 0.527 & 4 & 1.018 & 1 & 0.650 & 1 \\
\hline EU & 0.387 & 5 & 0.885 & 2 & 0.512 & 4 \\
\hline Switzerland & -0.007 & 6 & -0.393 & 6 & -0.104 & 6 \\
\hline Japan & -0.370 & 7 & -1.102 & 7 & -0.553 & 7 \\
\hline Norway & -2.317 & 8 & -1.181 & 8 & -2.033 & 8 \\
\hline
\end{tabular}

The Z statistics for the Aggregate Measure of Protection show that Norway is an extreme outlier. In contrast, the top five countries are clustered within a relatively narrow range of about 0.4 to 0.7 standard deviation greater openness than the mean. For revealed openness, the $\mathrm{Z}$ statistic shows a greater dispersion. For example, Australia ranks first and the United States ranks fourth on revealed openness, while their two rankings happen to be just the reverse on the AMP. But the intensity of the dispersion is greater on revealed openness ( $\mathrm{Z}$ ratios of 1.108 versus 0.196$)$ than on the aggregate measure of protection $(0.678$ versus 0.527$)$. The effect of the greater intensity of variation on revealed protection (except for Norway) is indirectly to give this criterion greater weight when the two approaches are averaged into the composite, even though once again the weightings are three-fourths for the AMP Z statistic and one-fourth for the revealed openness $Z$ statistic. On this approach, then, the result is to place Australia at the top of the composite market access ranking, New Zealand second, the United States third, and the EU fourth.

Because the revealed openness measure is not obtained by a full model of trade, it is unclear whether its weighting should be increased even indirectly because of the greater dispersion, so it is unclear that the composite ranking based on the $\mathrm{Z}$ statistics is preferable to that based on the simple weighting of table 3. It is useful to recall that revealed openness is included primarily because of the traditional concern about tacit protection in Japan, and because Japan is toward the bottom of the rankings on all the measures, the usefulness of the additional information from the simple revealed openness measure is subject to doubt.

As a result, the best interpretation of the final rankings is probably that there is a cluster of three countries all relatively close to each other at the top of the market access ordering: the United States, Australia, and New Zealand; that Canada and the European Union follow closely behind; Switzerland has noticeably lower access; and at the bottom are Japan and especially Norway.

\section{Disaggregating the EU}


For most purposes EU protection can appropriately be seen as uniform across EU member countries. Tariff rates in particular are identical. Because of the importance of agricultural protection in the overall protection estimates, however, and considering that there is some variation in the extent of agricultural subsidies across EU member countries, it is useful to consider whether disaggregation to the member level results in a wide or narrow range of individual country protection levels. If the range is wide, then there is additional information for the process of ranking individual industrial countries. If the range is narrow, then the EU aggregate serves well as the measure for each of the individual member countries for purposes of ranking protection relative to other countries.

Table 5 reports estimates of agricultural subsidies in individual EU member states. The total is set equal to the $€ 51$ billion actual Aggregate Measure of Support reported to the WTO (2002). The country shares in this total are based on agricultural support provided under the European Agricultural Guidance and Guarantee Fund in 2000 (EU, 2001, p. 6), plus member government budgetary expenditures on agriculture (OECD, 2002b, p. 88).

Table 5

Agricultural Protection in the EU (percentages)

$\begin{array}{lrrrrr}\text { Country } & \begin{array}{l}\text { Agricultural } \\ \text { output as } \\ \text { \% of GDP }\end{array} & \begin{array}{l}\text { Share in } \\ \text { EU farm }\end{array} & \begin{array}{c}\text { Subsidy } \\ \text { subsidies }(\%)\end{array} & \begin{array}{c}\text { Subsidy } \\ \text { tariff equiv. } \\ (\%)\end{array} & \begin{array}{r}\text { Total tariff } \\ \text { equivalent } \\ (\%)\end{array} \\ \text { Austria } & 2.1 & 2.8 & 32.0 & 19.5 & 100.1 \\ \text { Belgium } & 1.5 & 2.5 & 35.0 & 20.6 & 101.9 \\ \text { Denmark } & 2.9 & 3.1 & 30.5 & 18.9 & 99.1 \\ \text { Finland } & 3.4 & 2.5 & 28.2 & 18.0 & 97.6 \\ \text { France } & 3.0 & 23.1 & 28.4 & 18.1 & 97.7 \\ \text { Germany } & 1.2 & 14.1 & 28.9 & 18.3 & 98.0 \\ \text { Greece } & 6.4 & 6.0 & 39.1 & 22.0 & 104.1 \\ \text { Ireland } & 4.4 & 4.0 & 44.6 & 23.6 & 106.9 \\ \text { Italy } & 2.8 & 11.8 & 18.5 & 13.5 & 90.0 \\ \text { Luxembourg } & 0.9 & 0.1 & 21.3 & 14.9 & 92.4 \\ \text { Netherlands } & 2.8 & 3.8 & 17.2 & 12.8 & 88.8 \\ \text { Portugal } & 3.6 & 1.7 & 21.3 & 15.0 & 92.4 \\ \text { Spain } & 3.8 & 12.6 & 28.2 & 18.0 & 97.6 \\ \text { Sweden } & 1.9 & 2.0 & 21.6 & 15.1 & 92.6 \\ \text { UK } & 1.3 & 9.9 & 24.3 & 16.3 & 94.7 \\ & & & & & \\ \text { EU } & 2.3 & 100.0 & 26.4 & 19.6 & 100.2\end{array}$

As shown in the table, there is significant variation across EU member countries in agricultural subsidies. These range from 17.2 percent of agricultural value added in the 
Netherlands to 44.6 percent in Ireland, averaging 26.4 percent for the EU as a whole. ${ }^{20}$ These subsidy rates can be translated into tariff-equivalents by applying the method in Annex III, using a uniform EU ratio of domestic output at world prices to imports. ${ }^{21}$ The resulting tariff equivalents of subsidies range from 12.8 percent in the Netherlands to 23.6 percent in Ireland.

When these tariff equivalents are chained to the uniform EU agricultural tariff estimate of 67.4 percent, the combined total tariff equivalent in agriculture ranges from a low of 88.8 percent in the Netherlands to 106.9 percent in Ireland. It turns out, however, that after applying sectoral weights (table 2) to these individual-country agricultural protection rates and the uniform EU protection rates for the other sectors, the resulting aggregate protection measure lies in a narrow range. The low is 17.5 percent tariff-equivalent in the Netherlands, and the high, 20.0 percent in Ireland (adjusted import weight basis). The full range is thus close to the EU aggregate estimate of 19.1 percent. $^{22}$ Disaggregation of the EU thus provides little additional information for the purpose of ranking protection levels among industrial countries.

\section{Comparison with Alternative Studies}

Bouet et al (2001, p. 36) have constructed what they call "MacMaps" measures of protection that take account of the fact that the various preferential regimes mean that different rates of protection are applied to different supplying countries. They emphasize that although MFN protection in tariffs, specific duties, and tariff rate quotas are higher in the EU than in the United States, the aggregate level of protection in the EU is lower than in the U.S. because of the greater incidence of discriminatory regimes and preferential agreements.

Table 6

"MacMaps" market access protection rates against developing countries cereals other agr. other prim. textiles \& other services Composite clothing manufact.

$\begin{array}{lrrrrrrr}\text { US } & 2.5 & 18.1 & 1.2 & 22.4 & 11.7 & 0 & 11.8 \\ \text { EU } & 24.3 & 20.1 & 0 & 12.4 & 1.8 & 0 & 9.7 \\ \text { Japan } & 20.9 & 18.0 & 0.3 & 20.7 & 1.8 & 0 & 9.0\end{array}$

Sectors: average for imports from Morocco, Brazil, China.

Composite includes all countries.

Source: Bouet et al

\footnotetext{
${ }^{20}$ Data on country value added in agriculture are from OECD (2002c).

${ }^{21}$ Data on individual member country imports of agricultural goods from outside the EU are not readily available, and in any event could be misleading considering that imports into a given port of entry (such as Amsterdam) might be transported for consumption elsewhere within the EU.

${ }^{22}$ The individual estimates of the Aggregate Protection Measure are: Austria, 19.0 percent; Belgium, 19.3; Denmark, 18.9; Finland, France, Germany, and Spain, 18.7; Greece, 19.6; Ireland, 20.0; Italy, 17.6; Luxembourg, Portugal, and Sweden, 18.0; Netherlands, 17.5; and UK, 18.3 percent.
} 
Table 6 reports the composite MacMaps protection measure as well as sectoral levels reported for imports from developing countries. The striking difference in these estimates is that they place aggregate protection highest in the United States and lowest in Japan, the reverse of the ordering found here. Moreover, there is only a modest difference in the overall levels, ranging from only 9 percent in Japan to 11.8 percent in the United States. This too is a sharp contrast to the AMP range from 8.9 percent for the United States to 45 percent for Japan.

An examination of table 6 reveals the key influences behind these sharply different conclusions. First, the levels of agricultural protection identified by Bouet et al are far lower in Europe and Japan than those in the GTAP database (and used here). Thus, Bouet et al report protection in cereals and other agriculture at about 20 percent for Japan, whereas the GTAP database shows rates with a weighted average of 202 percent comprising such individual rates as 409 percent for rice, 249.2 percent for wheat, 20.2 percent for other grains, 47.3 percent for meat, and 287 percent for dairy products. These extreme differences cannot be explained by preferential treatment, as Japan does not exempt developing countries from protection in these goods. The radical differences in estimated tariff equivalents of agricultural protection are easily sufficient to explain the entire reversal in the Bouet et al results from those here.

Second, and in addition, the manufactured good protection rates in Bouet appear to use the non-MFN rates for China in the United States market (China is reported as facing average U.S. protection of 29 percent in manufactures other than textiles and apparel). While this may have been the case at the time of the Bouet et al study, China now enjoys "Normal Trade Relations" (the successor to MFN in U.S. parlance). Manufactured goods have a heavy weight, and the fact that Bouet et al place the U.S. rate at far above the EU and Japanese rates (11.7 percent versus 1.8 percent for both of the latter, for the three developing countries reported) also plays a major role in reversing the order of measured protection.

Third, Bouet et al (2001) also find substantially lower protection in textiles and apparel for the EU than is found in the GTAP database, the source used here. Here there may be more plausibility to the argument of greater EU incidence of preferential access for developing countries (but again the minimal foregone tariffs cast doubt on this). On the other hand, Bouet et al. do not account for the restrictive impact of MFA quotas, and therefore may underestimate the extent of protection.

In view of the widespread use by many researchers of the Global Trade Project Analysis (GTAP) database, and in view of especially the enormous difference in its agricultural protection rates from those in Bouet et al (2001), I am disinclined to accept the results of the latter. Nonetheless, the generally thoughtful methodology of the Bouet et al (2001) study means that it warrants serious consideration, and that accordingly further confirmation is desirable of the considerably higher agricultural and textile-apparel protection estimates used for the EU and agricultural protection estimates used for Japan in the present study as compared to those in Bouet et al.

Oxfam (2002) has developed an index of Double Standards to depict the level of 
protection of industrial countries against developing countries. It is composed of the following:

- Percent share of imports from non-LDC developing countries subject to tariffs over 15 percent;

- Same percent for LDCs;

- Average MFN rate for categories above 15 percent (tariff peaks)

- Highest tariff;

- Producer support as percent of farm income;

- Ratio of average tariff on processed to unprocessed agricultural goods;

- Average agricultural tariff;

- Percent of MFA quotas phased out by 2002;

- Average tariff on textiles and clothing;

- Number of antidumping investigations, 1995-2000.

Applying an unweighted average of the rankings on each of these criteria, Oxfam finds that protection is the highest in the EU, next in the United States, next in Canada, and the lowest in Japan.

Some of these benchmarks are germane. These include the average level of farm producer support, and the fraction of imports subject to tariffs over 15 percent. Others seem questionable, however. Given the arbitrary nature of the scope of many tariff categories as shown in figure A1-1 (Annex I) below, it is simply a roll of the dice to select the "highest tariff" as an indicator. One country could have a higher tariff on a trivial product than another on a more important product. The average tariff on textiles and clothing, reported as about 7-12 percent, fails to incorporate the important impact of quota protection. The number of antidumping investigations similarly seems to count what is available rather than what matters. A single antidumping case in one country on a large sector could be more important than tens or hundreds of small cases in another country.

In short, although some of the components of the Oxfam index warrant pursuit, and in particular, those based on tariffs could usefully be recalculated using the adjusted import weighting method set forth above, the overall index would appear to have serious limitations. The most important is that the index only has one gauge of agricultural protection out of ten components, whereas the analysis above suggests that agricultural protection is by far the most important influence on overall protection. ${ }^{23}$

\section{Conclusion}

Among the big three markets, this study finds that protection against developing countries is lowest (and market access highest) in the United States, intermediate in the EU, and highest (market access lowest) in Japan. Among seven industrial countries plus the EU, market access is ranked highest for a cluster of three countries close to each other at relatively low

\footnotetext{
${ }^{23}$ The European Commission (2002) also maintains that the Oxfam study has incorrect figures for tariff peaks and textile and clothing liberalization.
} 
protection levels (United States, Australia, New Zealand); followed by Canada and the EU, and then by Switzerland with somewhat lesser access. Significantly lesser market access is found in Japan and especially lowest-ranked Norway. For most countries, the results are driven heavily by estimates of agricultural protection, which is so high that it dominates the results even though the share of agriculture in total imports is modest. It is thus not surprising that the countries concentrated at the top of the market access league tend to be the agricultural exporting countries, and those at the bottom, agricultural importers. 


\section{Annex I}

\section{Weighting Protection}

This study proposes "adjusted import weighting" as the best approach to obtaining an aggregated weighted measure of tariffs or tariff equivalents of protection. The adjustment obtains an average between the observed import level and a measure of the import value that would occur if the protection were removed. For simplicity and transparency, this approach assumes a unitary price elasticity of demand for imports, and a global supply elasticity of infinity. The free-trade import volume equals the original volume plus a percent equal to the percent change in price resulting from removal of the tariff-equivalent protection. Thus,

$$
\text { A1) } M_{1}=M_{0}+M_{0}\left(-\alpha\left[\frac{-\tau}{1+\tau}\right]\right)
$$

where $\alpha$ is the absolute value of the price elasticity of demand for imports, $\tau$ is the tariff equivalent, and $(1+\tau)$ - often called the "force of the tariff" - is the ratio of the domestic price including protection to the world price. We seek as the basis for weighting an adjusted import base $M^{*}$ that is equal to the average of the actual import base $\left(M_{0}\right)$ and the hypothetical freetrade import base $\left(M_{1}\right)$. Assuming $\alpha=1$, then we have:

$$
\text { A2) } M^{*}=\frac{M_{0}+M_{1}}{2}=\frac{M_{0}}{2}\left(\frac{2+3 \tau}{1+\tau}\right)=M_{0}\left(\frac{1+1.5 \tau}{1+\tau}\right)
$$

Adjusted import weights along these lines should be preferable to actual import weights because of the problem of endogeneity of the latter (higher tariffs cause lower imports). An even simpler approach that avoids this problem is the use simple unweighted tariffs, but these in turn are susceptible to distortions caused by arbitrary differences in the coverage of individual tariff line categories. In support of the proposition that more error is introduced by using unweighted tariff category tariff averages than by weighting by adjusted (or even unadjusted) import values, consider Figure A1-1 below. For 115 categories drawn at random from the Harmonized Tariff System (HTS) of the United States (about 1 percent of the total U.S. nomenclature), the figure shows on the vertical axis the natural logarithm of the value of imports (in millions of dollars), and on the horizontal axis, the natural logarithm of the percentage rate ad valorem tariff. ${ }^{24}$ If the value scope of each tariff line item were about the same, and the main influence were that higher tariffs compress imports to lower levels, we would observe a downward sloping line with minimal dispersion around the line. If instead there is very wide variation between some categories with huge import values and some with small import values, and if there is little if any relationship in between the difference in import value magnitudes and the tariff rate, we should

\footnotetext{
${ }^{24}$ Note that unity (i.e. one percent) is added to each tariff before taking the logarithm, as the numerous cases of zero tariff would yield undefined logarithms. Note also that the negative figures on the vertical axis occur because in these categories imports are less than one million dollars.
} 
instead observe a relatively random dispersion. It is evident from the figure that the latter is the case.

To illustrate the arbitrariness of the categories, in this sample the largest import value occurs in item 8708.2950 , amounting to $\$ 4.8$ billion; the smallest, in 2915.4020 , comprising only $\$ 24,000 .^{25}$ The value multiple is a factor of 200,000 . So if a minimally important category has an unrepresentative tariff, the potential distortion to the average can be significant.

Figure A1-1

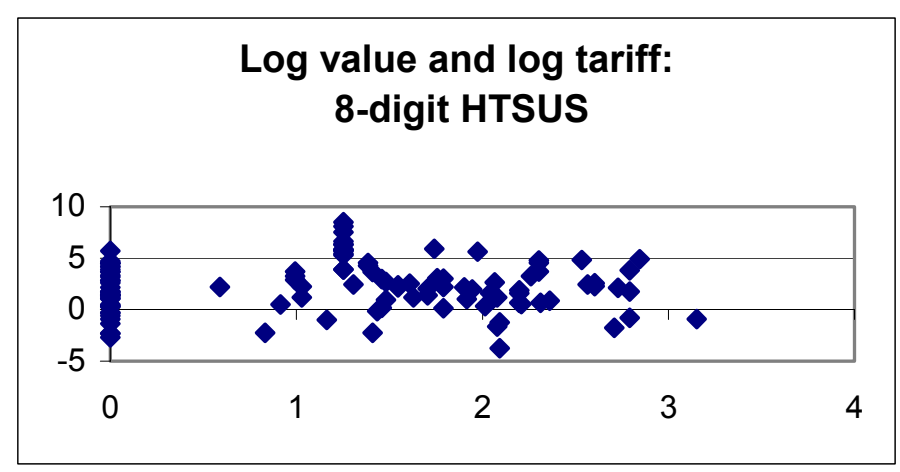

${ }^{25}$ These two items are, respectively: "Other" under "other parts and accessories of bodies ... of motor vehicles"; and "aromatic" under "saturated acyclic monocarboxylic acids, other". 


\section{Annex II}

\section{Tariff Level and Exporter Gains from Liberalization of Industrial Country Imports}

In measuring the importance of industrial country protection against developing country exports, it is worth considering whether there should be some non-linear weighting of the tariff, such as its square. For example, in the case of the importing country, the welfare benefit of liberalization tends to rises with the square of the tariff (Cline, 1995). It turns out, however, that use of the tariff itself provides a close approximation of the relevant effects for developing country exporters.

The gain from industrial country liberalization to the developing country exporter may be examined using Figure A2-1. In this diagram, the developing country exporter provides supply along curve SS. The industrial country importer has a demand curve for this product from this country shown by DD. The presence of a (fixed) tariff of " $t$ " reduces the demand to curve D'D'. Elimination of the tariff would cause equilibrium imports to rise from $\mathrm{M}_{0}$ to $\mathrm{M}_{1}$. Producer surplus for the exporting country will rise from area "a" to area $a+b+c+d$. Tariff revenue falls by area $e+f$. Consumer surplus in the importing country rises by area $e+f+\mathrm{g}$. The question for gauging importance of industrial country protection from the standpoint of the developing country is: how does the change in producer surplus change with liberalization, as a function of the size of the tariff?

Figure A2-1

Supply and Import from a Country

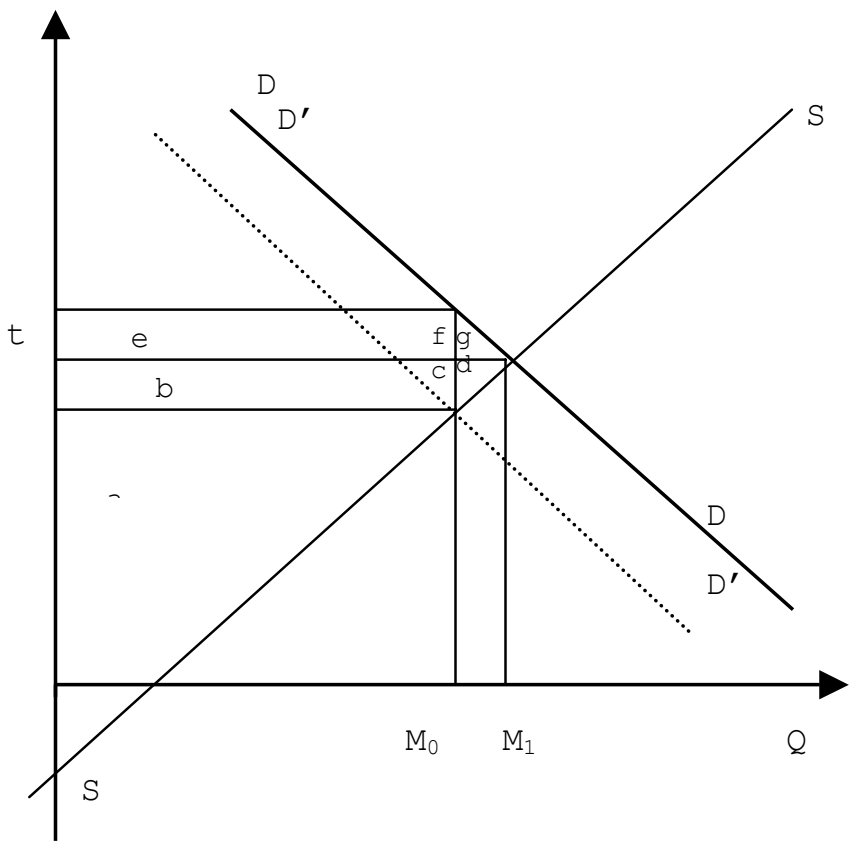

Demand for an Developing 
Let $\alpha$ be the absolute value of the price elasticity of demand. Let $\beta$ be the price elasticity of supply. When the tariff is removed, the change in quantity, $\Delta \mathrm{Q}$, must be the same on both the demand and supply sides. Defining $\mathrm{P}_{\mathrm{m}}$ as the import price, $\mathrm{P}_{\mathrm{e}}$ as the export price, and $\Delta$ as the change, we have:

A1) $\beta \frac{\Delta P_{e}}{P_{e}}=-\alpha \frac{\Delta P_{m}}{P_{m}}$

Elimination of an ad valorem tariff $t$ will remove the gap between the import and export price. The rise in the export price plus the decline in the import price must equal this gap, so:

A2) $\frac{\Delta P_{e}}{P_{e}}-\frac{\Delta P_{m}}{P_{m}}=t$

Substituting,

A3) $\beta\left(t+\frac{\Delta P_{m}}{P}\right)=-\alpha \frac{\Delta P_{m}}{P_{m}}$, and after manipulation,

A4) $\frac{\Delta P_{m}}{P_{m}}=-\frac{t \beta}{\beta+\alpha}$ and

A5) $\frac{\Delta P_{e}}{P_{e}}=\frac{t \alpha}{\beta+\alpha}$

Returning to Figure A2-1, normalize by setting the original export price at $\mathrm{P}_{\mathrm{e}}=1$. Then the absolute increase in the export price is also the proportionate increase, or $\left(t_{\alpha}\right) /\left(\beta^{+} \alpha\right)$. Areas $b+c$ will have the value: $\mathrm{M}_{0}\left[\left(t_{\alpha}\right) /\left(\beta^{+} \alpha\right)\right]=t K$ where $K=\mathrm{M}_{0}\left[\alpha /\left(\beta^{+} \alpha\right)\right]$. With respect to this area, then, the increase in producers' surplus is linear in $t$. The remainder of the increase in producers' surplus, area $d$, is comparatively much smaller, and is equal to: $d=0.5 \Delta \mathrm{M}\left[(t \alpha) /\left(\beta^{+} \alpha\right)\right]$. Considering, however, that $\left(\Delta \mathrm{M} / \mathrm{M}_{0}\right)=\beta\left(t_{\alpha}\right) /\left(\beta^{+} \alpha\right)$, we have: $d=0.5 \mathrm{M}_{0} \beta\left[(t \alpha) /\left(\beta^{+} \alpha\right)\right]^{2}$. Adding the three areas of increased producers' surplus: 
A6) $b+c+d=M_{0} \frac{t \alpha}{\beta+\alpha}\left[1+\frac{\beta}{2} \frac{t \alpha}{\beta+\alpha}\right]$

The increase in producers' surplus thus has a main component that is linear in $t$ and a minor component that rises with the square of $t$. Considering that in most cases $t$ is far less than unity, this second term involving the square of $t$ will be much smaller than the linear term. As a first approximation, then, the change in producers' surplus from tariff removal will rise linearly with the size of the tariff.

As an example, suppose that both the supply and demand elasticities are unity. Then the change in producers' surplus becomes: $b+c+d=M_{0}(t / 2)[1+(1 / 2)(t / 2)]=M_{0}\left[(t / 2)+\left(t^{2} / 8\right)\right]$. If the initial tariff is 5 percent, the linear component of the tariff removal $(.05 / 2$ or 2.5 percent of $\left.M_{0}\right)$ is far greater than the quadratic component $\left(.05^{2} / 8\right.$ or 0.03125 percent $)$. Even if the tariff is much higher, at 20 percent, the linear component contributes much more $(0.2 / 2$ or 10 percent of $\left.M_{0}\right)$ than does the quadratic component $\left(0.2^{2} / 8\right.$ or 0.5 percent $)$.

The broadly linear size of the producers' surplus gain with the size of the tariff removed contrasts with the quadratic relationship of the traditional welfare gain with the size of the tariff. The reason is simply that the net welfare gain ignores transfers from tariff revenue to consumers' surplus $(e+f)$ and producers' surplus $(c+d)$. As a result, it is only the "little triangles" stemming from consumer and producer surplus increment on the increase in imports (in Figure A2-1, areas $g$ and $d$, respectively) that constitute a net welfare gain. As just shown, the component $d$ does rise with the square of the tariff. In the example with $\alpha=\beta=1, g=d$ so the sum of consumer and producer surplus net of the transfer away from tariff revenue also rises with the square of the tariff. 


\section{Annex III}

\section{The Tariff Equivalent of Agricultural Subsidies}

In figure A3-1, the domestic supply curve would be $\mathrm{S}$ without the subsidy, but shifts rightward to S' with the subsidy, which reduces production cost by the vertical distance between the two curves. This increases domestic output volume from OA to OB. Domestic demand is given by curve DD. World supply is available at price $p_{w}$, but because of the tariff $t$ the price to the consumer is $p_{w}(1+t)$. In the absence of the subsidy, imports would be in the amount AC. In the presence of the subsidy, the are only BC. The question is thus: what is the tariff-equivalent that would have the same effect as the subsidy, i.e. in suppressing imports from $\mathrm{AC}$ to $\mathrm{BC}$ ?

Figure A3-1

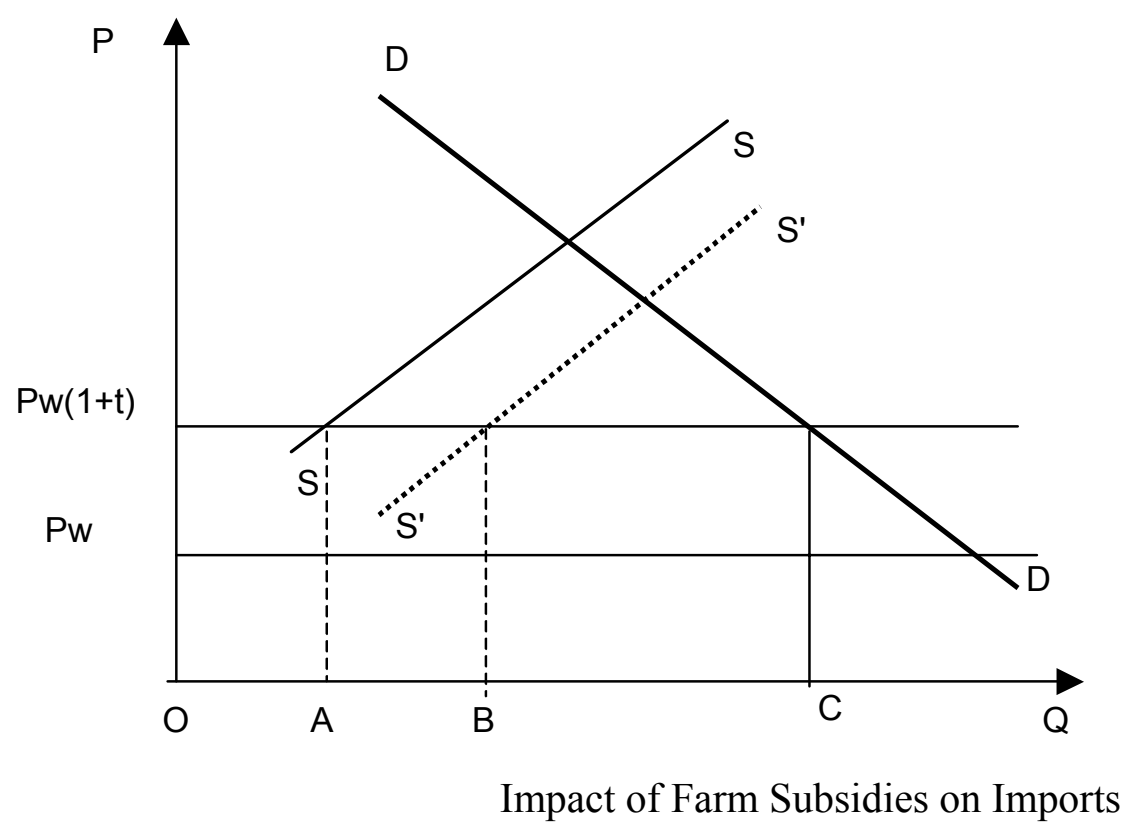

Let $\mathrm{V}_{\mathrm{d}}$ be the value of domestic agricultural output at domestic prices. Then defining $\mathrm{Q}_{\mathrm{d}}$ as the value of domestic output at international prices, we have $\mathrm{Q}_{\mathrm{d}}=\mathrm{V}_{\mathrm{d}} /(1+t)$. Suppose the domestic subsidy is the fraction $s$ of domestic market value of agricultural output (where the market value excludes the amount of the subsidy as the consumer does not pay it). Suppose the elasticity of domestic supply is $\varepsilon$. Then we can obtain the counterfactual level of domestic output (at world prices) in the absence of subsidy, or $\mathrm{Q}^{*}$, as:

$A 6) Q_{d}^{*}=Q_{d} /(1+s \varepsilon)$ 
That is, an increase in the producer price of the good in the proportion $s$ will raise supply by the proportion $s \varepsilon$, and in the absence of the subsidy output would have been observed output divided by unity plus this proportion.

Now consider what would have been the level of imports in the absence of the subsidy:

$$
A 7) M^{*}=M+\left(Q_{d-} Q_{d}^{*}\right)=M+(s \varepsilon) \frac{Q_{d}}{(1+s \varepsilon)}
$$

The proportionate reduction in imports attributable to the subsidy is thus:

A8) $\frac{\Delta M}{M^{*}}=\frac{-[(s \varepsilon) /(1+s \varepsilon)] Q_{d}}{M+[(s \varepsilon) /(1+s \varepsilon)] Q_{d}}$

If the price elasticity of demand for imports is unity, then the price increase to the consumer that would have been needed, in the absence of the producer subsidy, to suppress imports back to the observed level from its otherwise larger level, will also be in this proportion. The absolute value of equation A8) thus gives the tariff equivalent of the production subsidy if the price elasticity of import demand is unity. Moreover, as both $Q_{d}$ and imports are at world prices, they may be directly compared, and their ratio defined as: $\lambda=Q_{d} / M$. We may thus rewrite A8) as the tariff equivalent of the subsidy, equal to:

$$
\text { A9) } \tau=\frac{[(s \varepsilon) /(1+s \varepsilon)] Q_{d}}{\left[Q_{d} / \lambda\right]+[(s \varepsilon) /(1+s \varepsilon)] Q_{d}}=\frac{[(s \varepsilon) /(1+s \varepsilon)]}{[1 / \lambda]+[(s \varepsilon) /(1+s \varepsilon)]}
$$

A potentially counterintuitive result of this estimation is that the tariff-equivalent of the domestic subsidy rises with the ratio of domestic output to imports (in view of the reciprocal of $\lambda$ in the denominator). The economic meaning is that a country that has small imports and large domestic output will be causing a proportionately large further reduction in imports with only a modest subsidy. Conversely, a country with virtually no domestic output will have a deminimus tariff-equivalent of domestic subsidies because the resulting increase in domestic output and reduction in imports will be small relative to imports. 


\section{Annex IV}

\section{Sources for Data on Tariffs and Tariff-Equivalent Protection}

The primary source of tariff data for agriculture and textiles used in this study is the database developed by the Global Trade Analysis Project (GTAP) at Purdue University (see Dimaranan and McDougall, 2002). Data are taken from the most recent version of the database (Release 5). Developed for use with the GTAP computable general equilibrium model, the database aggregates tariff data drawn from various sources to fit the sectors and regions of the model.

- For agriculture, the GTAP database draws upon the Agricultural Market Access Database (AMAD) in addition to the other databases above and tariff bindings reported to the WTO. The AMAD database is maintained by a consortium of national and international entities (available at http://www.amad.org). Tariff rates represent either applied rates for 1998 (or closest available year) or MFN bound rates where applied rates are unavailable. Where commodities are subject to tariff rate quotas, the tariff for that line is reported as an average between in-quota and out-of-quota tariff rates. Moreover, where commodities are subject to specific duties, the GTAP database converts them to ad valorem equivalents.

- For textiles and apparel, the database draws on Francois and Spinanger (2002) to compile export tax equivalents that measure the restrictiveness of quotas under the Multi-Fiber Arrangement. The estimates reflect the average restrictiveness of the quotas on exports to the United States and European Union over the period 1997-1999. Following the GTAP5 database, US rates are applied to Canada. Tariffs on textiles and apparel are reported on a country by country basis and are taken from the same source as the other manufactures data in the GTAP5 database.

For manufactures (excluding textiles and apparel), the estimates in this study use tariff data as presented in WTO (2002) and Gelhar (1997). WTO (2002) reports simple average bound MFN tariff rates on industrial goods. Because bound and applied tariff rates tend to be very close to one another in developed countries, use of the bound rates is unlikely to skew the results. Bilateral tariff rates in Gelhar (1997) are calculated based on the use of the GTAP Database, Version 2, and therefore reflect levels of protection prior to the Uruguay Round. This is not a significant problem, however, because there is no reason to believe that relative protection against developing versus developing countries has changed with the implementation of the Uruguay Round.

Lastly, it should be noted that tariff rates for manufactures, agriculture, and textiles and apparel are bilateral MFN rates, and generally do not capture the impact of various preference schemes. The one significant exception to this rule is that zero tariffs are imposed on trade between countries that comprise a free trade area (e.g., between the US, Canada, and Mexico in NAFTA).

Data on trade flows are drawn from several sources, which are documented in the main text. 


\section{References}

Cline, William R., 1995. "Evaluating the Uruguay Round," World Economy, vol. 18, no. 1, January, pp. 1-23.

Cline, William R., 1990. The Future of World Trade in Textiles and Apparel (Washington: Institute for International Economics, Revised Edition,

Dimaranan, Betina V. and Robert A. McDougall (2002), Global Trade, Assistance, and Production: The GTAP 5 Data Base. Center for Global Trade Analysis, Purdue University. Available at http://www.gtap.agecon.purdue.edu.

EU, 2001. Commission of the European Communities, " $30^{\text {th }}$ Financial Report on the European Agricultural Guidance and Guarantee Fund: EAGF Guarantee Section" (Brussels: European Commission, October)

European Commission, 2002. "Comments from the Commission on 'Rigged Rules and Double Standards' (Brussels: European Commission, May). Available at: http://europa.eu.int/comm/trade/pdf/oxfamreply.pdf

Francois, Joseph and Dean Spinanger (2002), "ATC Export Tax Equivalents," Chapter in Dimaranan, Betina V. and Robert A. McDougall, Global Trade, Assistance, and Production: The GTAP 5 Data Base. Center for Global Trade Analysis, Purdue University.

Gelhar, Mark, Denice gray, Thomas W. Hertel, Karen M. Huff, Elena Ianchovichina, Bradley J. McDonald, Robert McDougall, Marinos E. Tsigas, and Randall Wigle, 1997. "Overview of the GTAP Data Base," Hertel (1997), pp. 74-123.

Gibson, Paul, John Wainio, and Daniel Whitley, 2002. "Agricultural Tariff Data," in Dimaranan and McDougall (2002), ch. 16.C.

Hertel, Thomas W., ed., 1997. Global Trade Analysis: Modeling and Applications (Cambridge: Cambridge Univ. Press).

IMF, 2002a. International Monetary Fund, International Financial Statistics (Washington: IMF, April)

IMF, 2002b. International Monetary Fund, Direction of Trade Statistics, CD Rom (Washington: IMF, April)

MacLaren, Donald, "An Evaluation of the Cairns Group Strategies for Agriculture in the Uruguay Round," in Hertel (1997), pp. 212-34. 
OECD, 2002a. Organization for Economic Cooperation and Development, Tariffs and Trade:

OECD Query and Reporting System (Paris: OECD, CD Rom).

OECD, 2002b. Organization for Economic Cooperation and Development, Agricultural Policies in OECD Countries: Monitoring and Evaluation (Paris: OECD).

OECD, 2002c. Organization for Economic Cooperation and Development, Annual National Accounts of OECD Countries (Paris: OECD). Available at: http:/www.oecd.org/EN/document/O,,EN-document-424-15-no-1-30531-0,00.html.

OECD, 2002d. Organization for Economic Cooperation and Development, International Trade in Goods Statistics (Paris: OECD). Available at: http://www.oecd.org/EN/statistics/0,,EN-statistics-422-nodirectorate-no-1-no-24,00.html.

Oxfam, 2002. Rigged Rules and Double Standards: Trade, Globalisation, and the Fight against Poverty (Oxfam, March). Available at: www.maketradefair.com.

UNCTAD, 1999. Quantifying the Benefits Obtained by Developing Countries from the Generalized System of Preferences. (Geneva: UNCTAD)

USITC, 2002. United States International Trade Commission online database, at: http://dataweb.usitc.gov/.

WTO, 2001. International Trade Statistics 2001 (Geneva: World Trade Organization). Available on: www.wto.org.

WTO, 2001. "Market Access: Unfinished Business, Post-Uruguay Round Inventory and Issues" (Geneva: World Trade Organization)

Available on: www.wto.org. 